\title{
Confusion reigns over compassionate use of AIDS drug
}

Back in March, Glaxo (or Glaxo Wellcome as it is now called) announced that supplies of its promising - but as yet unapproved - AIDS drug 3TC were running low. As a result, the company felt it necessary to cut back on the numbers of new patients using the drug as part of its compassionate use programme. News of the apparent shortages came at a time when preliminary clinical trial data looked promising, demand for compassionate use of 3TC was soaring, and Glaxo was shifting into high gear to prepare 3'TC for regular sale.

Patient quotas were instituted to deal with the shortage. But, in July, after a reevaluation of its inventory, and in the face of harsh criticism from the AIDS community and doctors, particularly in France (the principal market for AIDS drugs in Europe), Glaxo announced - to the surprise of many - that the 3TC shortage was not as severe as was first thought. The apparent about-face by Glaxo, which AIDS groups are claiming as a partial victory, has, nevertheless, left many patients and doctors confused about who now qualifies for the compassionate use of 3TC.

The decision in August of the Agence Française du Médicament, an agency similar to the US Food and Drug Administration, to step in (at Glaxo's request) and help manage the distribution of 3TC, has done little to ease the frustration. Confusion still reigns, for example, over the patient inclusion criteria.

"We have shown that AIDS activists can successfully oppose the dictates being handed down by the major pharmaceutical companies," says Franck Fontenay of TRT5, a consortium of five French AIDS associations. The victory is bittersweet, however, because the confusion has led to a significantly diminished demand for 3TC, according to many doctors prescribing the drug.

The international compassionate use programme for 3TC (Lamivudine) began in 1993, which coincided with the start of clinical trials to test the efficacy of 3TC in combination with AZT. The drug was was made available to individuals with fewer than $300 \mathrm{CD}^{+} \mathrm{T}$ cells per $\mathrm{mm}^{3}$ who had developed an intolerance or were resistant to other antivirals. At that

\section{IMAGE \\ UNAVAILABLE FOR COPYRIGHT REASONS}

Glaxo Wellcome's French facility: target of attack by AIDS tivists protesting shortages of trial AIDS drug 3TC. time, little was known about the effects of 3TC on the progression of AIDS.

This changed late last year, when the results of four (two European, two in the United States) phase II clinical trials evaluating the safety and efficacy of the combination therapy were first made public at meetings held in Glasgow last November and Washington, DC last February. The data showed that patients who had never before taken an antiviral agent had significant and prolonged augmentation of their CD4+ $\mathrm{T}$ cells while at the same time they experienced a decrease in viral load.

"No treatment has ever done this," says Christine Katlama of the Pitié-Salpétrière hospital in Paris, which accounts for 50 percent of the compassionate use requests for 3TC in France. "I don't want to say that it is the definitive solution to the AIDS problem, but it is better than any monotherapeutic treatment," she adds.

These encouraging - though as yet preliminary - results triggered a significant increase in the demand for the compassionate use of 3TC: Worldwide, the numbers increased from 550 new patients a month last December to 1,000 patients a week the following March.

The flood of requests led Glaxo to announce that it would be unable to meet demand until early next year. With 22,000 patients enrolled worldwide as of May 1995, "the compassionate use programme has become the largest of its kind," says Laure Thibaud, a spokesperson for Glaxo (France).

As a result, the company asked doctors to restrict access to 3TC under a quota of 460 new patients a week -350 in the United States, and 110 in Europe and Australia combined. "We hoped this would only be a temporary situation," says Thibaud.

News of the drug shortage sparked a wave of protests among AIDS groups, particularly in France. ACT-UP, for example, protested outside Glaxo's head office in Paris and at its manufacturing facility near Evreux in Normandy. Glaxo should have anticipated the increased demand and scaled up production accordingly, says François Houyez of ACT-UP in Paris. Glaxo counters the criticism by saying that decisions like that are not made overnight.

Many French doctors prescribing 3TC also stepped into the fray and began a letter-writing campaign to Glaxo. Jacques Leibowitch of the Garche hospital, near Paris, filed a suit against the company because he was unable to obtain 3TC for one of his patients. The patient was first treated with AZT and ddC, without success. Leibowitch requested that his patient be accepted into the 3TC compassionate use programme, but Glaxo declined his request on the grounds that the patient had not tried a third antiviral agent, ddI, first. The hearing was last month, and a verdict is expected later this month.

To the surprise of many, Glaxo announced in July that - after a review of its inventory - stocks of 3TC were greater than previously thought. As a result, the company agreed to double its patient quota for the programme to more than 600 a week in the United States and 220 for the rest of the world. Many felt, however, that Glaxo had bowed to public pressure.

At the same time, the Agence Française du Médicament announced that, through its new distribution system, 3TC will be available only to individuals with between 50 and 200 $\mathrm{CD}^{+}$cells per $\mathrm{mm}^{3}$. This is the range where the 3TC-AZT combination therapy, has shown the most promising results, says Daniel Vittecoq, an agency official. Many doctors and AIDS activists believe, however, that these limits lack a scientific basis, and expect the agency to extend the programme to include individuals with fewer than $50 \mathrm{CD}^{+}$ cells per $\mathrm{mm}^{3}$.

CATHERINe TASTEMAin Paris 